\title{
SHAMANISM AND THE IMAGE OF THE TEUTONIC DEITY, ÓĐINN
}

\section{A. Asbjørn Jøn}

While coming to deeply consider the nature and practices of Finnic shamanism, it is important to recognise the vital role that shamanic godheads, such as Väinämöinen, Ilmarinen, Lemminkäinen and Joukahainen have played in the Finno-Baltic pagan tradition as well as in the development of deep cosmological understanding and unity within a specific mortal shaman. By this, it is suggested that such divine figures have not only influenced the conception of the shaman's role in the minds of those aspiring to such an occupational position, but that they also influenced the young shaman's personal Weltanschauung. Additionally, such mortal religious leaders may have influenced popular conceptions of Finno-Baltic pagan cosmology - through their powerful and influential role within pre-Christian communities. Therefore, deep analysis of the cosmology and shamanic practices of pre-Christian Finnic society largely depends upon the accurate mapping of the aforementioned deities, and the recognition of any elements that may have been transferred upon their godheads at a later time due to the contact with other cultures.

As scholars such as Peter Andreas Munch, Sophus Bugge and Wolfgang Golther have come to suggest - with relation to the now disproved hypothesis that the Ásatrú tradition was heavily influenced by Christian mythology - it is very hard to overestimate the power of the traveller's tale in relation to the process of cultural transference. ${ }^{1}$ Wide ranging lexical exchange between Finno-Baltic and Northern Teutonic peoples during the main composition period of Finno-Baltic magic and shamanic epic poetry (ca 200 B.C.550A.D.) is now largely accepted by scholars, and has in most cases been attributed to such early contacts (see Branch 1985: xxi). Therefore, it is also highly possible that some theological conceptions were also exchanged between the Teutonic and Finno-Baltic peoples during such early meetings. Such a theory highlights the possibility that an analysis of the Teutonic shaman god, Oðinn, focusing upon commonly recognised shamanic features may lead to a 
future recognition of ways in which both the shamanic Finno-Baltic gods and that godhead may have to some degree influenced each other. Accordingly, in the following paragraphs Óðinn's major shamanic attributes will be outlined with some of the close parallels to the shamanic practices of non-Teutonic peoples or deities being carefully noted.

There are several features of Óðinn's persona which indicate that he should be viewed as a master-shaman. In recent decades, many scholars have recognised this aspect of his persona, and many have even come to compare his various efforts to gain greater spiritual knowledge to those of shaman from geographic locations as diverse as Siberia and North America. ${ }^{2}$ However, most have limited their descriptions of his shamanic role to the like of Simpson's following comment:

Odin is the god of wisdom, especially the occult wisdom of seers and sorcerers [. /---/ He] was the patron and the divine prototype of seers and magicians, especially those who (like shamans in Arctic Europe and Asia in modern times) undergo terrifying initiations and communicate with other worlds in ecstasies and mediumistic trances (Simpson 1971: 215).

The first and most obvious indicators of Óðinn's shamanism are to be found in the myth of 'Óðinn's Ordeal'. The best surviving record of 'Óðinn's Ordeal' appears in the portion of the Hávamál that is generally called the 'Rúnatal'. In this myth, as A. G. van Hamel has suggested (van Hamel 1932); Óðinn submits to a shamanistic ordeal that ritually magnifies his ásmegin (divine strength). This ritual was enacted as an attempt to gain knowledge of and power over the runes - an eternal magical element, that are unique to Teutonic cosmology. Their nature is perhaps best illustrated by considering that their 'actual mysteries are timeless and were created - or more properly, "came into being" - with the emergence of the Nine Worlds out of Ginnungagap' (Thorsson 1991: 3).

To enact the ritual, Óðinn hung himself on Yggdrasill for nine nights, during which he received neither food nor wine. He also pierced himself with the point of a spear. Upon the completion of this ritual, Óðinn was able to recognise the runes and make them submit to him as their Rune-Master. This myth corresponds with 
the shamanist initiation rites of a number of peoples. Pipping has noted the similarity of the ordeal to the initiation rite of Finnish shaman (Pipping 1928). A similar technique is also used by shaman in Nepal. In Nepal, at the moment of a shaman's spiritual birth, they are required to tree-sit in a pine, which is regarded as being symbolic of the Tree of Life. During this period the initiates are left by themselves and are forbidden to eat; yet the rest of their tribe conducts a public feast. The initiated shaman is also blindfolded for the ritual. ${ }^{3}$ The fasting element is also common amongst shamanic initiations, with perhaps the most obvious parallel being the fasting of the Caribou Eskimo initiate shaman (see Rasmussen 1927: 82-85). We can also compare the moment of Óðinn discovering the runes, to the climax of the Siberian shaman's initiation. We have been told that at this moment:

he [/---/ obtains] the flash or illumination - a mysterious light which the shaman suddenly feels in the interior of his head. He is now able to discern things hidden from other human beings (Hunkin 1987: 678).

Additionally, with the aid of the work of the Boeotian biographer, Delphic priest and municipal officer of Chaeronea, Plutarch; we can confirm that parallels of this shamanic ritual have been used by Óðinn's Cult as a form of human sacrifice from at least 100 B.C. Plutarch recorded that the Teutonic tribe known as the Cimbri sacrificed themselves to appease their gods after being defeated in a battle. The said battle was fought against Caius Marius, and took place in ca 110 B.C. Plutarch's passage is significant here, because it clearly states that the tribe's preferred method of sacrifice was hanging by the neck, from tres. ${ }^{4}$ However, in this instance, because there were no trees in the area the Cimbri had performed the sacrifice by having themselves trampled to death by cattle and oxen.

Other indicators of this role are the myths that reveal that Óðinn's horse Sleipnir could carry him to the Underworld. ${ }^{5}$ Verrier Elwin has noted that the Muria people's shaman hold a belief about being carried to another world on the back of an eight-legged horse (Elwin 1947: 150). This belief contains many parallels to the Teutonic tales about Sleipnir. Furthermore, Elwin also recognised that the Muria people have created mythicised songs about this type of 
voyage. These songs probably represent the same theological processes as a Teutonic song, such as Baldrs draumar.

Óðinn also possesses the shape-changing power - sjónhverfing (taking on false appearances through the power of optical or magical illusions), a shape-changing power which in many ways reflects an ability to exude hypnotic suggestions upon all who are, in an immediate vicinity. When using this shape-changing power, Óðinn can take on the shape of a 'fugl eða dýr, fiskr eða ormr' (Sturluson 1952: 10), and travel to far off places. In this way he fulfils errands for either himself or for others - sometimes even travelling between worlds. From a variety of sources though, we know that this practice was extremely physically demanding. Interestingly, we may note that Celia Green has scientifically recorded the practice of similar out-of-body phenomena in modern times, suggesting a deeper truth to the myth (Green 1976: 13, 59, 68, 75, 82-84, 86, 93-100, 112-118, 120, 126, 129, 133, 138, 154, 161). It is an ability that is a common attribute of the shaman. Shaman usually employs such a trance induced mechanism of self shape-changing to travel to other worlds and fight spirits. By employing this technique, the shaman 'controls his trance movements between the world of men and the spirit world' (Zweig 1981: 86), moving between them with great speed and efficiency. There are many examples of the use of this power throughout both Teutonic and FinnoBaltic myth and folklore. As Kvideland and Sehmsdorf have suggested, tales of this kind are so common that they have come to hold their own classification, as Legend Type 3080 (Kvideland \& Sehmsdorf 1994: 71-74). ${ }^{6}$ Eliade has also commented about the close relationship between to Óðinn's shape-changing, and 'the [shape-changing] practices of Siberian shamans' (Eliade 1989: 381). Additionally, we can note similar practices amongst the shaman of many other cultures, such as those of the Sora people. Piers Vitebsky, the Head of Social Sciences at the University of Cambridge's 'Scott Polar Research Institute', has noted that the Sora shaman have the shape-changing power to 'slip out of their bodies and their souls also turn to monkeys' (Vitebsky 1995: 92).

Óðinn's animal companions are also reflections of his shamanism. Óðinn's most commonly explored connection to shamanism through these animals is his connection to ravens. ${ }^{7}$ These two birds often 
perch on his shoulders. 'Pá sendir hann í dagan at fljúgja um allan heim ok koma peir aptr at dögurðarmáli' (Sturluson 1988: 32); bringing him news from the four corners of Mišgaršr. As Eliade has suggested, Óðinn's birds, Munin and Hugin, probably represent:

in highly mythicised form, two helping spirits in the shape of birds, which the Great Magician sent (in true shamanic fashion!) to the four corners of the world (Eliade 1989: 381).

Spirits taking the form of birds play a large role in the shamanism of many cultures, and Óðinn's relationship with the raven may even suggest some distant parallel to the shamanic Inuit belief in The Raven Father. ${ }^{8}$

Furthermore, Óðinn's companions, the Valkyrja, also reflect his shamanism. ${ }^{9}$ However, in order to recognise this, we must first consider the history of the interpretation of the name. In 1899, Professor H. Munro Chadwick suggested that the Anglo-Saxon word, walcyrge (wælcyrie), 'may reflect an earlier conception' (Chadwick 1899: 47-48) of these spirits, than the Old Norse word, 'Valkyrja'. He also suggested that walcyrge would have probably originally referred to those women who performed human sacrifices, and then used that blood for divination. Chadwick did acknowledge that the walcyrge possessed supernatural powers, yet suggested that these powers 'appear [...] to have been of the werewolf class'(Chadwick 1899: 48). In this way he saw their ascent to the Valhöll as a later development. This interpretation would function in perfect unison with the label, oskmeyiar, which has been applied to the Valkyrja; reflecting the usage of óskasynir to refer to the Einheriar who were the mortal warriors chosen to fight with Óðinn in Ragnarøkr. ${ }^{10}$ Therefore, we may in one way see the Valkyrja as former humans, who were sibyls in life, who assist warriors to travel to the Valhöll. This corresponds to the shamanic notion that it is the deceased shaman who assist the newly dead to find their path to the underworld.

This may be contrasted with the beliefs of the Sora people, who also believe that the souls of the chosen deceased, 'help [... them] on the difficult path to the underworld' (Vitebsky 1996: 92). The Siberian shaman also believe in such beings, and see them as female spirits who have a close connection to an individual shaman. 
Therefore, as Eliade has suggested, the image of the Valkyrja does become a difficult image to separate from that of the "celestial wives" [...] of the Siberian shamans' (Eliade 1989: 381). Moreover, we can note that the Maori's shaman tradition also believes inspiritwives, yet we do not know enough about their nature to make a firm comparison between them and the Valkyrja at this point. ${ }^{11}$

The Valkyrja also possess the power of shape-changing. Perhaps the most obvious example of this is that they often took 'the form of crows and ravens on the battle-field' (Davidson 1989: 73). Therefore, we must note that these servants of Óðinn possess at least some shamanic powers themselves. This emphasises Óðinn's role as the master shaman, positioning the Valkyrja as lesser shaman in his service. The master/pupil power relationship between Óðinn and the Valkyrja can be loosely compared to the relationship between Väinämöinen and Joukahainen.

Additionally, we know that Óðinn taught his sacral priests how to perform the Ásatrúarmann's religious rites. This reflects the practices of the Votyak people. V. M. Mikhailowski has noted that among the Votyak, the position of shaman is often granted directly by their foremost deity. Correspondingly, this deity then becomes the shaman's mentor, providing him with lessons both in waking visions, and in dreams (Mikhailowski 1894: 62-100, 126-158).

To some extent, Óðinn's position as a great shaman god is also reflected by the beliefs of the Oglalla Sioux, who possess a culture which is generally recognised as shamanic. The Oglalla Sioux believe that their greater god, Wakan-Tanka, holds many of the powers that the Teutons attribute to Óðinn. The Oglalla Sioux believe that it is only because of Wakan-Tanka's generosity that their shaman have 'wisdom and the power to heal and to make holy charms' (Curtis 1907: 38). This belief would seem to correspond with the Germanic ideal that Óðinn selected his sacral priests, and then taught them how to perform his ceremonies. When loosely comparing the two cultures in this way - the Oglalla Sioux's holy charms then be connected as a parallel to the runes. Further strengthening this comparison is our knowledge that the runes were used in Teutonic pagan magico-medicine rituals. 
Therefore, in summary conclusion, it should be noted that Óðinn's shamanic qualities manifest in ways that are closely parallelled by the master-shaman of distant cultures. This observation, in conjunction with the pre-existent knowledge of early contact and lexical borrowing's between the Finno-Baltic and Teutonic peoples, would suggest that deep analysis of the development of both FinnoBaltic shamanic deities and Óðinn may reveal instances in which tales that were traditionally associated with the exploits of one of these figures were transferred upon another. Such a discovery would certainly support the study of Estonian shamanism, as it would speed the process of recognising purely Estonian elements of shamanic practice and belief.

\section{Comments}

1 This critical school came to claim that Ásatrú cosmology 'ist nur als nachbildung christlicher Vorstellungen verstandlich' (Golther 1895: 350). See Munch 1926 and Bugge 1889.

${ }^{2}$ One such writer is Ed Fitch (see Fitch 1993: 4).

3 This ritual has been discussed by Vitebsky (1995: 62)

4 This is recorded in: Plutarch 1864: 510.

5 This belief is recorded in The Poetic Edda (1994: 117).

${ }^{6}$ In the case of the referred volume, the Teutonic myth and folklore is represented by Nordic accounts, and the Finno-Baltic by Finnish accounts.

7 This is a very strong connection, and through it Óðinn has even aquired the name - 'Hrafnáss', or 'Raven-god'.

8 This belief has been explored by Piers Vitebsky (1996: 217).

${ }^{9}$ On the Valkyrja see Olsen 1908.

10 These terms are discussed in Chadwick 1899: 10.

${ }^{11}$ On Maori spirit-wives, see Eliade 1989: 133. 


\section{References}

Branch, M. A. 1985. Introduction. Kalevala: The Land of the Heroes. London.

Bugge, Sophus 1889. Studien über die Entstehung der nordischen Götter und Heldensagen. Munich.

Chadwick, H. Munro 1899. The Cult of Othin. London.

Curtis, Natalie 1907. The Indians'Book. New York.

Davidson, Hilda Ellis 1989. The Seer's Thumb. The Seer: in Celtic and Other Traditions. Ed. by Hilda Ellis Davidson. Edinburgh, 6678.

Edda 1994. Baldrs draumar. The Poetic Edda. Trans. by L. M. Hollander. Austin, 117-119.

Eliade, Mircea 1989. Shamanism: Archaic techniques of ecstasy. Trans. by Willard R. Trask. London.

Elwin, Verrier 1947. The Muria and Their Ghotul. Bombay.

Evans, David A. H. (Ed.) 1986-1987. Hávamál. Viking Society for Northern Research Text Series. No. 7, 2 vols. London, I, strophes 138-145, pp.68-70.

Fitch, Ed 1993. The Rites of Odin. Llewellyn's Teutonic Magic Series. Minnesota.

Golther, Wolfgang 1895. Handbuch der germanischen Mythologie. Leipzig.

Green, Celia 1976. The Decline and Fall of Science. London.

van Hamel, A. G. 1932. Ošinn hanging on the Tree. Acta Phililogica Scandinavica, 7, pp. 214-219.

Hávamál 1986-1987. Edited by David A. H. Evans, glossary and index by Anthony Faulkes. Viking Society for Northern Research Text Series number 7, 2 vols. London, I, strophes 138145, pp. 68-70.

Hunkin, O. J. W. 1987. Religion. The Oxford Companion to the Mind. Edited by Richard L. Gregory. Oxford, pp. 677-679.

Kvideland, Reimunf \& Sehmsdorf, Henning K. 1994. Scandinavian Folk Belief and Legend. The Nordic Series, Vol 15. Edited by Reimunf Kvideland \& Henning K. Sehmsdorf. Minneapolis.

Mikhailowski, V. M. 1894. Shamanism in Siberia and European Russia, Being the second part of Shamanstvo. Journal of the Royal Anthropological Institute, 24. Trans. by Oliver Wardrop. 
Munch, Pater Andreas 1926. Norse Mythology: Legends of Gods and Heroes. Scandinavian Classics, Vol. XXVII. Trans. by Sigurd Bernhard Hustvedt, revised by Magnus Olsen. London.

Olsen, Magnus (Ed.) 1908. Völsunga saga. Völsunga saga ok Ragnars saga loðbrókar. Samfundet til udgivelse af gammel nordisk litteratur 36. Cophenhagen.

Pipping, Rolf 1928. Oden i galgen. Studier i Nordisk Filologi utgivna genom Hugo Pipping, 18, pp. 1-13.

Plutarch 1864. Caius Marius. The Lives of the Noble Grecians and Romans. Trans. by Arthur Hugh Clough. London, pp. 494525 .

Rasmussen, Knut 1927. Across Arctic America. London.

Simpson, Jaqueline 1971. Everyday Life in the Viking Age. London.

Sturluson, Snorri 1952. Ynglingasaga. Edited by Elias Wessén. København.

Sturluson, Snorri 1988. Edda: Prologue and Gylfaginning. Edited by Anthony Faulkes. London.

Thorsson, Edred 1991. Futhark. Maine.

Vitebsky, Piers 1995. The Shaman: Voyages of the Soul Trance, Ecstasy and Healing from Siberia to the Amazon. Living Wisdom Series. London.

Vitebsky, Piers 1996. The Arctic Regions. World Mythology. Edited by Roy Willis. London.

Zweig, Paul 1981. The Adventurer. New Jersey. 